\title{
Did UK 'dump' contaminated feed after ban?
}

Paris. British exports of animal feedstuffs potentially contaminated with the agent that causes bovine spongiform encephalopathy (BSE) more than doubled in the years following their prohibition in ruminant feed in the United Kingdom itself, according to official government statistics.

Britain banned the inclusion of ruminantderived protein in ruminant feed in June 1988 (although not in all meat and bone meal). In September 1990, it extended this to prohibit the inclusion of specified bovine offals (SBOs) - the most infective parts, such as brain and spinal cord - in all meat and bone meal.

But export statistics from HM Customs and Excise show that whereas UK exports of animal feeds had remained almost constant in the years leading up to the 1988 ban, they more than doubled the next year (see figure, below). Most of this increase was accounted for by exports to France.

Some of the feed exported before the SBO ban came into force would have been contaminated. Moreover, although Britain banned the export of SBOs at the same time as it introduced the SBO ban within the country, even feedstuffs exported in later years may have been contaminated, given that it is now acknowledged that the ban was not properly enforced.

Nonetheless, many veterinary experts defend the UK's decision to continue exporting feed. One member of the UK Spongiform Encephalopathy Advisory Committee, for example, argues that while the 1988 ban prohibited the inclusion of ruminant protein in rations for ruminants, it allowed the use of meat and bone meal in pigs and poultry rations. There was therefore no reason not to export it, he says.

Some experts in other countries, however, disagree with the UK's action. "They knew at that time that meat and bone meal was dangerous, yet they exported it and spread the danger of new cases of BSE arising in member states," says Udo Weimer, an official at the German agriculture ministry's animal diseases division. He adds that when

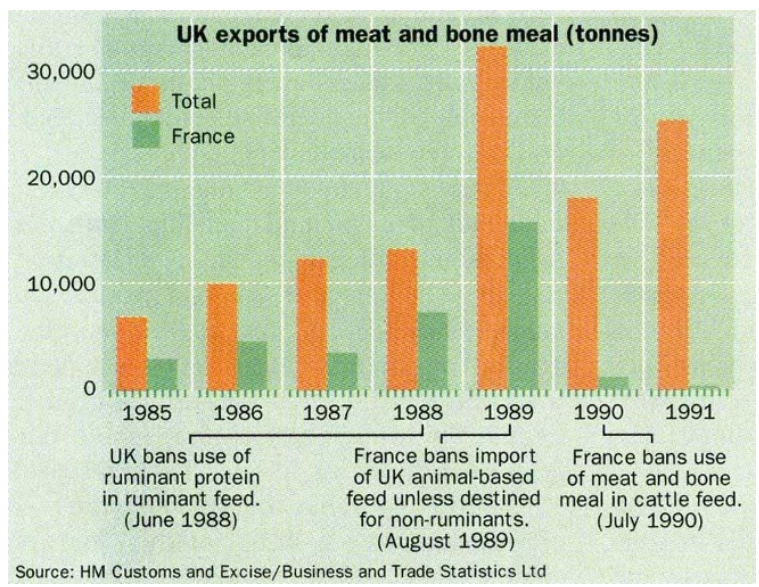
(Indeed, one factor involved in the spread of BSE in the United Kingdom was that inclusion of meat and bone meal in animal feeds jumped from 1 to 12 per cent during the $1980 \mathrm{~s}$, a shift that resulted from a fall in the value of the pound and a corresponding increase in the cost of soya and fish meal.)

The French ministry of agriculture says that it was powerless to prevent imports of UK meat and bone meal, given that this needed to circulate freely countries to put in place all the uarantees needed.'

The official also claims that a Dutch
veterinary surgeon working at the port of Rotterdam told him at the time that he was being dumped, and also speculated that some may have been rebagged and reim-

Whether there was dumping or not, exports were eagerly snapped up because of pathology at the Centre Nationale d'Etudes Vétérinaires et Alimentaires at British ban had caused prices of UK meat and bone meal to plummet.

before the SBO ban would have been conta the vast majorand poultry rations, as its toxicity would otherwise have resulted in more cases of BSE in continental Europe, whereas only around with a total of around 160,000 in the United gdom) the imports of "contaminated feed" on BSE worse if France had not traditionally used lower concentrations of meat and bone meal in cattle feed, typically around 1.5 per rotein feeds were mainly used imports were banned by the mem-
ber states of the European Union, the United Kingdom continued to erinary Association says that he warned the government at the time but that his warnings were ignored. "I badgered our chief veterinary a 'poisoned food' it was immoral to export it," he claims. But, he adds:

\section{IMAGE \\ UNAVAILABLE \\ FOR COPYRIGHT REASONS} Eager feeders: feed exports more than doubled in 1989.

within the then European Economic Community. But it points out that, as an intermediate measure, it prohibited imports of UK meal in August 1989 unless this was destined for animals other than ruminants. "But it would have been much better if the United Kingdom had not exported it in the first place," says a ministry official.

At the time, the European Commission felt it was unnecessary to apply a Community-wide ban on UK feeds, says an official from its agriculture directorate. One reason, he claims, is that the United Kingdom had given the commission assurances that it would not export feed - an assurance that was not respected, he adds - and member states had implemented their own import bans. (Germany, for example, banned imports of UK meat and bone meal in 1990.)

Another reason was that the commission felt it would be difficult to enforce a ban, he says, as feed is not labelled precisely. Even now, EU law requires feed to be labelled only as containing "products of animal origin" and not to provide further details. "Industry has never been keen on telling farmers what it puts in rations," he says, adding that there is some justification in that contents are adjusted continuously on the basis of the costs of ingredients.

Indeed, one problem in interpreting export statistics is that these group all feeds containing animal matter under the heading "flours, meals and pellets of meat of meat offal; greaves". They make no distinction, for example, between feed prepared from poultry or from cattle.

It is thus impossible to tell whether UK exports respected the 1990 UK ban on the export of feeds containing specified bovine offals. The statistics show, however, that as member states in the EU began to impose their own import bans on UK meat and bone meal around 1990, UK exports continued to grow through increased sales to countries outside the EU.

In 1991, for example, Israel imported almost 10,000 tonnes of UK feed and Thailand 6,200 tonnes, both up from zero a few years previously. Savay says that he 
would like assurances that such exports did not contain specified bovine offals. "Until we know the exact nature of the exports to Thailand and other countries and what became of them, there exists the risk that they may have been given to cows and caused further contamination," he says, pointing out that many countries still lack surveillance networks for BSE.

For his part, A. Shimshony, Israel's director of Veterinary Services and Animal Health, is adamant that the imports into Israel consisted only of meat and bone meal derived from poultry. He points out that Israel banned the import of all mammalian meat and bone meal for feed use in 1990 .

Moreover, imports of meal derived from poultry were permitted only from mills certified to have never produced feeds of other animal origin, he says, in order to eliminate the risk of cross-contamination Indeed, Israel has a BSE surveillance network and has not detected any cases.

Johnston says that Israel's vigilance would be the exception rather than the rule, given that meat and bone meal is produced from cadavers, bones and other wastes from a variety of animals, and that it is consequently often difficult to distinguish what is and what is not derived from ruminants. Half a gram of infected meal is enough to kill a cow, he adds.

Indeed, Israel's action in 1990 seems almost clairvoyant. Most feed mills use the same equipment for producing all feeds. As a result, contaminated material intended for use in pig and poultry rations in the United Kingdom may have found its way into cattle feed. This is now acknowledged probably to account for most of the 27,100 cases of BSE in Britain since the introduction of the 1988 feed ban. But it was only in March this year that Britain recognized the risk and imposed a comprehensive ban on the feeding of mammalian-derived meat and bone meal to all farm animals.

While the recriminations over UK feed exports are likely to continue, the mad cow crisis has sent a shockwave through the feed industry that bodes well for the future safety of feed. The EU's council of agriculture ministers agreed in April that by the end of the year all rendering plants must convert to batch processing methods that use a temperature of $133{ }^{\circ} \mathrm{C}$ and pressure of 3 bars for at least 20 minutes. This means that "other epidemics of this nature cannot occur again", says Weimer.

Meanwhile, feedstuffs are not the only controversial exports from the United Kingdom in the BSE crisis. Many European countries are remaining remarkably discreet about the fact that they have also imported large numbers of breeding animals from BSE-infected herds in the United Kingdom, many of which could be incubating the disease. This means that although the Netherlands, for example, is listed as BSE-free, its disease status would probably be better described as unknown.

Declan Butler

\section{Science agencies benefit as Congress eases up on cuts}

Washington. The US Congress is quietly retreating from its previously stated objective of slashing the federal budget this year, leaving most science agencies in better shape than they were only a few months ago.

Bloodied by last year's prolonged budget conflict - from which it wrested billions of dollars of spending cuts but no political credit - the Republican-controlled Congress is now rushing to complete spending bills which will be more generous than expected, postponing tough action to balance the budget.

The House of Representatives, for example, is expected to complete each of the thirteen appropriations bills needed for the 1997 financial year, which begins 1 October, by early next month.

Next week, the Energy and Water appropriations subcommittee, chaired by John Myers (Republican, Indiana), will mark up a bill requiring cuts of around $\$ 200$ million. Earlier in the year, Myers was asked to make cuts of $\$ 1$ billion. His refusal to do so helped force an agreement last week between the House and the Senate which freed up an extra $\$ 4$ billion across the government.

The first bill of major importance to science funding was approved by the Veterans Affairs, Housing and Urban Development and independent agencies (VA-HUD) subcommittee two weeks ago. The subcommittee approved a budget for NASA of $\$ 13.6$ billion, compared with $\$ 13.8$ billion requested by President Bill Clinton. The $\$ 200$ million was cut from the Mission to Planet Earth programme. Science programmes at the Environmental Protection Agency would receive $\$ 540$ million, against $\$ 580$ million requested by Clinton.

Also in the VA-HUD bill, the National Science Foundation would get $\$ 3.25$ billion, against $\$ 3.325$ billion requested by Clinton. But the subcommittee was allocated an additional $\$ 350$ million under the new House-Senate agreement, and science lobbyists are working to get some of it for the National Science Foundation.

This week, the Labor, Health and Human Services and Education subcommittee was expected to mark up a bill that will contain more money for the National Institutes of Health $(\mathrm{NIH})$ than the $\$ 12.4$ billion requested by Clinton. The president's proposal would have allocated most of the NIH's 4 per cent budget increase to the construction of a new clinical centre (see Nature 380, 187; 1996). But John Porter (Republican, Illinois), the chairman of the subcommittee, is expected to secure a 6.5 per cent increase in NIH research grants, as well as money to start the new centre, in his bill.

Colin Macilwain

\section{European vote raises bioethics stakes}

Munich. The European Parliament is being asked to vote later this month on a resolution opposing all research on human embryos and on people who cannot give informed consent - referred to as "legally incapacitated persons" even though such research is currently allowed in several of the 15 member states of the European Union that the parliament represents.

Such a vote would have no legal status. But it would be intended to influence a draft bioethics convention being drawn up by the Council of Europe, a body representing 39 European countries, one of whose aims is to defend human rights. The new draft was approved last week by the council's executive, and will be voted on at its parliamentary assembly in September.

An initial draft of the convention was approved last year by this assembly by a narrow majority, on the understanding that it would undergo extensive rewording aimed at finding a consensus between countries such as Germany, which would like tough restrictions on research on humans and embryos, and France and Britain, which want more flexibility.

The new draft tightens up the wording, making explicit, for example, that the creation of human embryos for research purposes should be prohibited. But it accepts the principle that embryo research is otherwise allowable. It also allows research in principle on legally incapacitated persons.

Responding to an initiative of the European Parliament's research committee, headed by Christof Tannert, a member of Germany's Social Democrats, the legal affairs committee of the parliament last week approved a position paper requesting a long list of amendments to the draft.

Individual members of the Council of Europe will not be required to ratify the bioethics convention, even if the new draft is approved in September. But it will provide a form of indirect political pressure on countries such as Germany if it appears to have widespread approval.
Alison Abbott 